\title{
Perceived impact of tourism on rural and urban communities in Botswana
}

\author{
J. Pansiri ${ }^{1}$ \& R. N. Mmereki ${ }^{2}$ \\ ${ }^{I}$ Department of Tourism and Hospitality Management, \\ Faculty of Business, University of Botswana, Botswana \\ ${ }^{2}$ Department of Management, Faculty of Business, \\ University of Botswana, Botswana
}

\begin{abstract}
The purpose of this paper is to examine the impact of tourism on urban and rural communities in Botswana. Based on past work on tourism impacts, this paper identifies a set of tourism impacts and analyzes their implication for tourism development in Botswana. The study is based on a review of the literature which provided a theoretical understanding of the impact of tourism on communities. This theoretical understanding was then tested using primary data that was collected through a survey of 595 respondents from Gaborone, Kasane, Maun and Mochudi in Botswana. The study was designed in such a way that it captured tourism impacts in both urban and rural communities. The study found that tourism affect host communities positively and negatively, and that respondents' perceived effects of tourism on their communities differed significantly dependent upon whether one is employed in the tourism industry, have ever visited any tourism facility, and was born in that particular community
\end{abstract}

Keywords: tourism impacts, Botswana, tourism development, local communities, economic development, developing countries, economic diversification.

\section{Introduction}

Tourism has been identified as an engine of growth and an industry with potential to contribute to Botswana's economic diversification that will help to broaden the country's economic base (Commonwealth Sectretatiat [1]). Tourism is currently Botswana's second largest contributor towards GDP and is therefore 
a major source of revenue and economic diversification (Botswana Tourism Board [2]). Furthermore, tourism has the potential to increase Botswana's foreign exchange earnings and government revenues, and help generate employment mainly in the rural areas. It is argued that tourism also has the potential to stimulate other economic activities and reduce rural-urban and further distribute economic benefits to rural areas, and contribute to reducing socio-economic disparities among the country's different areas (Commonwealth Sectretatiat [1]).

According to the Hospitality and Tourism Association of Botswana [HTAB] [3] tourism in Botswana is growing significantly. For instance, the HTAB observes that Botswana tourist arrivals have grown from 1, 048,845 in 2001 to 1 , 034,871 in 2005 (which represent a negative growth). Tourism expenditure was estimated to grow from 2.2 billion Pula (US\$410 million) in 2004 to 2.6 billion Pula (US\$473 million) in 2005, representing an average annual growth rate of 15.3 percent over the past five years (HTAB [3]). According to HTAB [3, p. 6], employment in the tourism industry is "estimated to have engaged 17,000 people in core tourist facilities a large number of which will be in the Delta and Chobe region, and this figure will increase with a consideration for related sectors such as transport, agriculture, Immigration and others." Because of these appealing tourism economic benefits, the Botswana government is committed to further develop tourism as a way of enhancing the industry's contribution to the GDP. The promises of what tourism can do to a country and its communities are overwhelming. Care has to be taken to insure that Tourism does not bring its unintended negative impacts. For that reason it is essential to periodically assess tourism impacts on communities, using communities' perceptions. Therefore the purpose of this study is to examine Botswana's residents' attitudes towards tourism development. In doing so, this study uses the perceptions of residents from four geographical locations, namely Gaborone, Mochudi, Kasane and Maun. Maun and Kasane were chosen because they are the two major tourist destinations in Botswana where tourism is highly developed. Gaborone was chosen due to it being the biggest city and capital city of Botswana. If there are any urban tourism development initiatives, they will be started in Gaborone.

\section{Local impact perceptions of tourism}

The successful planning for tourism development requires the active support and involvement of local communities (Gutierrez et al. [4]). Gutierrez et al. [4] further maintains that host communities have a stake in ensuring that tourism does not compromise their quality of life. It is widely acknowledged in the literature that community support for tourism is imperative for successful tourism (Butler, [5]; Gutierrez et al. [4]; Haley et al. [6]; Kibicho, [7]; Wilson et al. [8]). Diedrich and Garc1'a-Buades [9, p. 496] argue that "understanding and assessing tourism impacts in communities is important in order to maintain sustainability and long-term success of the tourism industry."

Butler [5] observes that there are indications that the favorable attitudes by local communities regarding tourism may be changing due to costs of tourism 
such as land and housing costs, labor shortages, immigration of foreign workers, inappropriate behavior by tourists and a feeling of general loss of control over their communities and lives. Therefore, "understanding the antecedents of support by local residents towards tourism development is crucial for local governments, policymakers, and businesses, because the success and sustainability of any development depends on active support of the local populations" (Gursoy \& Rutherford [11, p. 495]).

The literature on tourism impacts is extensive. Gursoy et al. [10], Gursoy and Rutherford [11], and Haley et al. [6] summarize the development of this literature since the early 1970s. The argument for mush research on tourism impacts is that by its nature, the tourism industry inevitably induces impacts that are both beneficial and adverse. Most research in this are uses residents' perceptions of tourism development (Gursoy et al. [10]; Haley et al. [6]. Gursoy et al. [10] modeled host community support for tourism based on perceived impacts as having two dimensions - costs and benefits, as factors influencing communities' reaction towards tourism development. They found that the host community support for tourism is affected by "the level of concern, ecocentric values, utilization of resource base, perceived costs and benefits of the tourism development" (Gursoy et al. [10, p. 79]). This is purported by Diedrich and Garci'a-Buades [9] whose study found that tourism does result in good and bad changes in communities.

It is argued that residents who perceive that are likely to benefit economically from tourism development are likely to support it (Gursoy et al. [10]; Gursoy and Rutherford [11]; Haley et al. [6]). Haley et al.] found that "as income level fell, the residents were more likely to support increased tourism and those with lower incomes were more likely to accept their city becoming more of a destination". From this perspective, developing countries governments have accepted not only the importance of tourism in economic development but have also played a dominant role in the planning process. Government planning seems to be one of the most outstanding factors for poor tourism performance in these countries, particularly in Africa. (Dieke [12]; Kibicho [7]) and a significant number of communities in these countries accept tourism initiatives with the hope that tourism will better their livelihood (Kibicho [7]).

However, communities may not always support tourism. Wilson et al [8, p. 136] cite McCool and Marten who states that "like other industries, tourism can bring changes to communities, such as general disruption of residents lives owing to increased population during the tourist season, increase in crime, displacement of residents by new developments, conflict of values, and impacts upon the local culture". Negative impacts should not outwear positive ones. And positive impacts should really be meaningful so that so that communities see the benefits of tourism development.

There is a lot of emphasis on the economic contribution of tourism in Africa, a content that for over decades has been affected by problems of high unemployment rates. The attempts to develop tourism may then be highly appealing. Without delivering any meaningful positive results, communities may be disillusioned (Mbaiwa [13-15]; Kibicho [7]). For instance, Botswana 
describes tourism as an 'engine of economic growth' and a means for economic diversification (Government of Botswana [16]) because of its potential to contribute significantly to employment creation and the country's GDP. However, Mbaiwa's [13-15] research in the Okavango Delta debunks this myth. Mbaiwa [14] argues that foreign companies and investors dominate the ownership of tourism facilities in the Okavango Delta. According to him, only $17.9 \%$ of the tourism facilities are wholly citizen owned with $23.3 \%$, which are jointly owned. The rest are foreign owned. This ownership has ramifications for employment and economic benefits to the economy and Okavango community in particular. Mbaiwa [13] argues that tourism businesses in the Okavango delta employed 1658 people, accounting for $(16.6 \%)$ of the formal employment in the tourism sector in Botswana. However, most of these people occupy unskilled jobs such as manual labourers, drivers, house cleaners, cleaners, night watchmen, gatekeepers, and cooks. These jobs pay low salaries as compared to management positions held by expatriates (Mbaiwa, 2004, 2005a). Mbaiwa [13] alleges that about $62 \%$ of the junior workers in the tourism industry in the Okavango delta are paid salaries less than P900.00 (\$180.00) per month. His findings collaborate Ndulamo [17] who found that about two-thirds of the citizens employed in tourism-related jobs in Maun earned less than P954.78 (\$190.96).

These low levels of income mean that tourism destinations like the Okavango Delta continue to experience high levels of poverty. The NWDC cited by Mbaiwa [15] argues that the majority of people living in the Okavango delta can be classified as rural and they live in poverty. Low levels of income, high levels of poverty in rural tourism destinations in Botswana are compounded by what repatriation of tourism revenue due to foreign ownership of tourism businesses. The tourism industry in Botswana is criticized for its failure to retain revenue in the country. It is estimated that over $70 \%$ of the tourism revenue in Botswana is repatriated outside the country. For instance, Mbaiwa [14, 15] observes that in 1997, while tourists who visited Botswana spent an estimated P1.1 billion (\$0.22 billion), 55\% or P605 million ( $\$ 121$ million) was spent outside Botswana, and $16 \%$ or P175 million (\$35 million) was lost through first-round linkages of receipts due tourist-related imports. "As a result, only $29 \%$ or P320 Million (\$64 million) was spent in Botswana on local goods, wages, taxes and other activities" (Mbaiwa [15], p. 216).

This paper assumes that residents of communities perceive tourism impacts differently based on their length of stay in the community affected by tourism, their home ownership status and whether one was born in that particular community. Further to this, the paper proposes that tourism impacts are also perceived differently because of the level of importance of tourism to ones' profession and employment status in the tourism industry. Therefore, two hypotheses are proposed:

\subsection{Hypotheses}

Hypothesis 1: Perceived tourism impacts are closely associated with the length of residence in a particular city/town/village, Home ownership in that particular place, and whether one was born in that particular place. 
Hypothesis 2: Perceived tourism impacts are closely associated with the importance of tourism to one's profession, and whether one is employed in the tourism industry.

\section{Methodology}

\subsection{Setting and sample}

Data was collected to test the two hypotheses. The study focused on both rural and urban communities in Botswana. This study adopted stratified random sampling to come up with a sample of potential respondents. This was based on four geographical locations namely Gaborone, Mochudi, Kasane and Maun. Once the locations were identified, information was collected from a random sample. The target was to administer 900 questionnaires for all the sampled locations. Research assistants were employed to administer the questionnaire randomly in order to collect the necessary data.

\subsection{Measures}

A questionnaire was used to assess tourism impact on the host community. The first 24 were adapted from Haley et al [6]. The robustness of this survey instrument is that it has been used in both rural (Perdue [18]) and urban (Haley et al. [6]) settings. Respondents were asked to rate their level of agreement with the statements on a five-point Likert scale from $1=$ 'strongly disagree' to $5=$ 'strongly agree'. Like in the Haley et al [6], p. 653] "each item was related to general aspects of tourism development, sharing an interest in a particular issue, thus enabling the creation of subscales". The other seventeen items were adapted from the World Tourism Organisation [19] where respondents were asked to rate their level of agreement with the statements on a five-point Likert scale from $1=$ 'strongly disagree' to $5=$ 'strongly agree'. Respondents were also asked about their opinion regarding tourism in their community and whether they would like more or less tourism in the future. Respondents were also asked to indicate the importance of tourism to their occupation, whether they have ever visited any tourism facility in this city/town/village, born in that particular city/town/village and employed in the tourism industry. This was in addition to their demographic profiles.

\section{Results}

\subsection{Sample}

The survey was performed from July 2009 to February 2010. In total, 593 respondents participated in the survey (Gaborone 44.7\%, Muchudi 22.8\%, Kasane $12 \%$ and Maun 20.6\%). The majority of the participants were young - up to 39 years of age (75.7\%). The sample included $38.9 \%$ males and $61.1 \%$ females. Respondents' profile also indicates that $77.3 \%$ were either employed or 
self-employed. A significant (63.8\%) number of them indicated that tourism is very important for their occupation. However, only $33.6 \%$ of them were employed in the tourism industry. Only $30.7 \%$ of them had at least a degree while the rest had either college or high school educational qualifications.

\subsection{Tourism impacts}

No single item is likely to provide a perfect representation of the impact of tourism in any given community. Therefore, such impact can be viewed from multiple perspectives, "where each item is expected to have a certain amount of distinctiveness even though it relates to the same concept" (Pansiri [20, p. 107]). Consequently, the impact of tourism was measured using 41.

Table 1: Results of PCA with Varimix rotation for perceived tourism impacts.

\begin{tabular}{|l|r|r|r|c|c|}
\hline ITEMS & $\begin{array}{c}\text { No of } \\
\text { Items }\end{array}$ & $\mathrm{M}$ & $\begin{array}{c}\text { Eigen } \\
\text { Value }\end{array}$ & $\begin{array}{c}\text { Cumulative } \\
\text { per cent } \\
\text { variance }\end{array}$ & $\begin{array}{c}\text { Cronbach } \\
\alpha\end{array}$ \\
\hline Social impact of tourism & 8 & 3.28 & 10.557 & 25.749 & .867 \\
\hline Direct Individual impact of tourism & 6 & 3.41 & 4.290 & 36.213 & .860 \\
\hline General economic impact & 4 & 3.79 & 2.678 & 42.745 & .784 \\
\hline Environmental impact & 4 & 3.56 & 1.959 & 47.523 & .768 \\
\hline Direct community economic impact & 3 & 3.00 & 1.831 & 51.989 & .832 \\
\hline $\begin{array}{l}\text { Impact of tourism on local } \\
\text { government }\end{array}$ & 4 & 3.76 & 1.491 & 55.627 & .618 \\
\hline $\begin{array}{l}\text { Impression of local community \& } \\
\text { quality of life }\end{array}$ & 4 & 3.81 & 1.340 & 58.895 & .722 \\
\hline Local development impact & 3 & 3.76 & 1.152 & 61.706 & .681 \\
\hline Local participation & 3 & 3.72 & 1.045 & 64.254 & .588 \\
\hline Cultural impact & 2 & 3.81 & 1.014 & 66.728 & .528 \\
\hline $\begin{array}{l}\text { Notes: M = Mean, SD= Standard Deviation, Bartlett's Test of Sphericity - Approx. Chi-Square } \\
=7812.827, d f=820, \mathrm{p}<0.000 ; \text { and KMO Measure of Sampling Adequacy = .882: Extraction } \\
\text { Method: Principal Axis Factoring. Rotation Method: Varimax with Kaiser Normalisation }\end{array}$ \\
\hline
\end{tabular}

\subsection{Data reduction}

Data reduction through exploratory factor analysis using Principal Component Analysis (PCA) as the extraction method and varimax rotation with Kaiser normalisation was conducted in order find out if the different variables were driven by the same underlying variable, that could help in identifying common themes, and to "to reduce the data set to a more manageable size while retaining as much of the original information as possible" (Field [21, p. 619]). All components with eigenvalues greater than 1.0 were extracted. Factor loadings less than 0.4 were suppressed for interpretative purposes (Field [21]). Table 1 shows that this process yielded ten themes with the Bartlett's Test of Sphericity Chi-Square of $7812.827(\mathrm{p}<0.000)$ and KMO Measure of Sampling Adequacy of .882 
Reliability analysis was then conducted on the ten sets of items to measure the internal consistency of the items loaded onto each factor. Table 1 shows that the Cronbach's alpha values for all the ten components were in excess of the required 0.5 criterion for reliability, which according to Nunally [20] meets the requirements for basic survey research. As a consequence, a cut-off value of 0.50 was used to measure reliability and all the themes were accepted. Therefore all the ten themes were accepted to be used for further analysis. Table 1 the ten themes together with the aggregated mean, eigenvalues, cumulative percentage and Cronbath alpha. Furthermore, the table also shows the means and standard deviations of all variables measuring the impact of tourism.

\section{Study results and discussion}

In this study, a two-step procedure was followed. PCA was followed by one-way analysis of variance (ANOVA) which was conducted to assess relationships between tourism impacts and independent variables. ANOVA was used to test for significant differences between the means of two or more groups. Levene's test was used to test violation of assumption of homogeneity of variance. In most of these analyses, the homogeneity of variance assumption was broken. Field [21] suggests that instead of correcting violations of homogeneity of variance by transformation of all the data, Welch's F-ratio can be reported. For this analysis, independent variables were categorical while dependent variables (tourism impacts) were continuous. This made use of values generated by factor analysis.

Four different levels of significance are used. These are $0.001,0.01,0.05$, and 0.10. Conventionally, if the significance value is small enough (less than 0.05) the null hypothesis is rejected, for instance that the variables are independent and accept the hypothesis that they are in some way related. However, previous social science research has accepted the 0.10 level of significance (Papadakis and Barwise [23]).

Hypothesis 1 tested whether perceived tourism impacts are closely associated with the respondents' length of residence in a particular city/town/village, Home ownership in that particular place, and whether one was born in that particular place. This hypothesis therefore wanted to test if attachment to a place results in perceiving the impact of tourism differently.

Table 2 shows that significant associations exists between the respondents' Length of Residence and perceived Social Impacts, Direct Individual Impacts, Direct Community Economic Impacts $(\mathrm{p}<0.001)$, and Local Participation (0.10). Similarly there exists significant relationships between the responds' ownership of a home in that particular town/city/village with perceived Direct Individual Impact, General Economic Impact, Impact of Tourism on Local Government $(\mathrm{p}<0.05)$, and Direct Community Economic Impacts $(\mathrm{p}<0.01)$. Few significant associations were found between the respondents' place of birth and perceived tourism impacts - Social Impacts, Direct Individual Impacts, and Impact of Tourism on Local Government $(\mathrm{p}<0.05)$. 
Table 2: $\quad$ Results of ANOVA for the influence of geographic and economic related characteristics on perceived tourism impacts.

\begin{tabular}{|c|c|c|c|c|c|c|c|c|c|c|c|c|}
\hline \multirow{4}{*}{$\begin{array}{l}\text { Perceived tourism } \\
\text { impacts }\end{array}$} & \multicolumn{12}{|c|}{ Independent Factors } \\
\hline & \multicolumn{6}{|c|}{$\begin{array}{l}\text { Geographic Related } \\
\text { Characteristics }\end{array}$} & \multicolumn{6}{|c|}{$\begin{array}{c}\text { Economic Related } \\
\text { Characteristics }\end{array}$} \\
\hline & \multicolumn{2}{|c|}{$\begin{array}{l}\text { Length of } \\
\text { residence }\end{array}$} & \multicolumn{2}{|c|}{$\begin{array}{c}\text { Home } \\
\text { ownershi } \\
p\end{array}$} & \multicolumn{2}{|c|}{$\begin{array}{c}\text { Born in } \\
\text { the } \\
\text { communi } \\
\text { ty }\end{array}$} & \multicolumn{2}{|c|}{$\begin{array}{l}\text { Occupati } \\
\text { on }\end{array}$} & \multicolumn{2}{|c|}{$\begin{array}{c}\text { Employme } \\
\text { nt in } \\
\text { tourism }\end{array}$} & \multicolumn{2}{|c|}{$\begin{array}{l}\text { Tourism } \\
\text { Facility }\end{array}$} \\
\hline & $\mathrm{d}$ & $\mathrm{F}$ & $\mathrm{d}$ & $\mathrm{F}$ & $\mathrm{d}$ & $\mathrm{F}$ & $\mathrm{d}$ & $\mathrm{F}$ & $\mathrm{d}$ & $\mathrm{F}$ & $\mathrm{d}$ & $\mathrm{F}$ \\
\hline $\begin{array}{l}\text { Social impact of } \\
\text { tourism }\end{array}$ & 4 & $10.5^{\mathrm{a}}$ & 1 & 1.4 & 1 & $5.9^{*}$ & 4 & $3.3^{*}$ & 1 & $3.1 \uparrow$ & 1 & $7.5^{\mathrm{a}}$ \\
\hline $\begin{array}{l}\text { Direct individual } \\
\text { impact of tourism }\end{array}$ & 4 & $5.6^{\mathrm{a}}$ & 1 & $4.6^{*}$ & 1 & $4.1^{*}$ & 4 & $6.0^{\mathrm{a}}$ & 1 & $42.6^{\mathrm{a}}$ & 1 & $5.9^{\mathrm{a}}$ \\
\hline $\begin{array}{ll}\text { General economic } \\
\text { impact }\end{array}$ & 4 & .51 & 1 & $4.9^{*}$ & 1 & 1.1 & 4 & $6.2^{\mathrm{a}}$ & 1 & $3.3 \dagger$ & 1 & $6.0^{*}$ \\
\hline $\begin{array}{l}\text { Environmental } \\
\text { Impact }\end{array}$ & 4 & 1.7 & 1 & .9 & 1 & .5 & 4 & 1.1 & 1 & $9.0^{\mathrm{a}}$ & 1 & .1 \\
\hline $\begin{array}{l}\text { Direct Community } \\
\text { economic impact }\end{array}$ & 4 & $7.7^{\mathrm{a}}$ & 1 & $9.4^{\mathrm{a}}$ & 1 & 1.7 & 4 & $9.5^{\mathrm{a}}$ & 1 & $17.4^{\mathrm{a}}$ & 1 & .0 \\
\hline $\begin{array}{l}\text { Impact of tourism } \\
\text { on local government }\end{array}$ & 4 & .6 & 1 & $4.0^{*}$ & 1 & $5.4^{*}$ & 4 & $2.4 \dagger$ & 1 & $12.5^{\mathrm{a}}$ & 1 & $3.0 \dagger$ \\
\hline $\begin{array}{l}\text { Local community \& } \\
\text { quality of life }\end{array}$ & 4 & .9 & 1 & .1 & 1 & .0 & 4 & .5 & 1 & .7 & 1 & 1.8 \\
\hline $\begin{array}{l}\text { Local development } \\
\text { impact }\end{array}$ & 4 & 1.8 & 1 & .3 & 1 & .6 & 4 & .8 & 1 & $9.9^{\mathrm{a}}$ & 1 & $\begin{array}{c}10.8 \\
\mathrm{a}\end{array}$ \\
\hline Local participation & 4 & $2.0 \dagger$ & 1 & .6 & 1 & 1.2 & 4 & $2.4 \dagger$ & 1 & .0 & 1 & 1.8 \\
\hline Cultural impact & 4 & .3 & 1 & .2 & 1 & 1.6 & 4 & 1.3 & 1 & .7 & 1 & .7 \\
\hline
\end{tabular}

Notes: $\mathrm{df}=$ Degree of freedom; $\dagger \mathrm{p}<0.10 ;{ }^{*} \mathrm{p}<0.05$; and ${ }^{* *} \mathrm{p}<0.01$

Hypothesis 2 tested whether perceived tourism impacts are closely associated with the importance of tourism to one's profession, whether one is employed in the tourism industry, and whether one has ever visited a tourist facility. Table 2 further shows that significant associations exists between the respondents' perception of the importance of tourism to their occupation and perceived Social Impacts $(p<0.05)$, Direct Individual Impacts, General Economic Impact, Direct Community Economic Impact $(p<0.001)$, Impact of Tourism on Local Government, and Local Participation $(\mathrm{p}<0.01)$. Significant associations also exist between being employed in the Tourism Industry and Social Impacts, General Economic Impact $(p<0.10)$, Direct Individual Impacts, Direct Community Economic Impact, Impact of Tourism on Local Government $(\mathrm{p}<$ 0.001), Environmental Impact, and Local development Impact ( $p<0.01)$. Lastly, significant associations exists between the respondents previous visitation to a tourist facility and perceived Social Impacts $(p<0.01)$, Direct Individual Impacts, General Economic Impact $(\mathrm{p}<0.05)$, Impact of Tourism on Local Government $(p<0.10)$, and Local development Impact $(p<0.001)$.

The relationship between Cultural Impact, Local Participation and Impression of Local Community \& Quality of Life with independent factors is very poor. Cultural Impact and Impression of Local Community \& Quality of Life was not significantly related to any of the factors while Local Participation was only 
significantly related to length of residence and Occupation $(\mathrm{p}<0.10)$. Cultural Impact, Local Participation and Impression of Local Community have the highest aggregate mean of 3.81 each. Tourism in my community/region helps stimulate local culture and crafts $(\mathrm{M}=3.81)$, Tourism improves the appearance of the city $(M=3.79)$, Tourism increases recreational opportunities $(M=3.87)$, the city should become more of a tourist destination $(\mathrm{M}=3.60)$ and that Tourism development increases the quality of life $(\mathrm{M}=3.98)$. Evidence from this study point to the fact that these perceptions are not influenced by any factors investigated in this study. More research is needed in this area.

The purpose of this study was to examine residents' attitudes toward tourism development in Botswana by using four geographical locations. This was fulfilled by testing two hypotheses using analysis of variance. Most of the variables used in this study have been used and analyzed differently in previous research. For instance, Haley et al [6] conducted factor analysis of 24 factors and produced two factors they called 'positive' and negative' factors, and then conducted hierarchical regression. On the other hand, Gursoy and Rutherford [11] grouped their variables into eleven items and then tested their model using sequential chi-square difference tests. This study produced ten items. This study results are consistent with previous studies in that tourism impacts are both negative and positive. However, the study's major contribution is that it splits the independent factors into two, geographic related characteristics (Length of residence, Home Ownership, and being born or not born in that community) and economic related characteristics (Importance of tourism to one's occupation, employment in Tourism, and whether they have visited any tourism facility before). This split is based on the understanding that perceived tourism impacts are dependent upon one being personally attached to the place and/or benefiting from tourism development in the area.

This study found that geographic related characteristics do not influence residents as much as economic related characteristics do. Geographic related characteristics are important for consideration regarding social and individual impacts of tourism, tourism's impact on the local economy and local government. On the other hand, economic related characteristics are influential in all except Impression of local community \& Quality of life, and Cultural impact.

\section{Implications}

This study has found that perceived tourism impacts are influenced by both geographic related characteristics (and economic related characteristics. However, economic related characteristics were found to be more influential than geographic characteristics.

This has fundamental imprecations regarding tourism development. Tourism developers should realize that the issue of tourism support by local communities is very complex (Gursoy and Rutherford [11]). People feel tourism's impacts more if they are personally involved with tourism, particularly in relation to their employment and whether they have visited any tourism sites before. However, 
people are part of the community and the community is concerned about how their resources are utilized. They are interested in seeing their local communities developing economically and issues relating to crime and environmental degradation arising from tourism being reduced. In developing tourism, governments in Africa often justify such initiatives by arguing that tourism would create jobs, and improve the local and national economy, but, as Butler [5] argues, tourism has "not always delivered the benefits that were forecast, or where those benefits have occurred, that the overall effects have not been those desired". Studies by Mbaiwa [13-15] have shown that although the contribution of tourism to the GDP may be increasing, local communities hardly benefit and are left to cope with 'negative' consequences of their local area being a tourist destination. These are issues that need policy makers to address because the usual support for tourism development by local communities on economic grounds may in the long run decline.

There is a big challenge relating to how communities can effectively participate in tourism. Policy initiatives directed at enhancing people's participation in tourism are necessary if they are to appreciate the role of tourism. More community based tourism initiatives are needed to make residents appreciate the contribution tourism makes to their livelihoods.

This study and its findings are not without limitations. The first limitation is that the study was limited to four geographical places only in Botswana and these opinions cannot be said to be representative of the whole Botswana. It is important that a nationwide sample be done that is not necessarily limited to high concentration of tourism only. This limitation is related to two factors: the fact that this study is part of a larger research that at the time of writing this paper, data had not yet been collected from one sampled village. Further to this, funds allocated to this study did not permit a large sample of towns and villages to be done due to the geographical spatiality of Botswana.

Secondly, this study made use of 41 closed ended statements related to specific tourism impacts. The positive thing with this approach was that most if not all of these statements have been used in past search on tourism impacts. It follows however that not all the impacts of tourism on communities can be possibly represented by these statements. The third limitation is that this study relied solely on one method. There are a growing number of tourism researchers calling for research programmes involving the triangulation of quantitative and qualitative methods (Downward and Mearman [24]; Oppermann [25]; Pansiri [26]; [27]). Studies on tourism impact such as this, can benefit from mixed methods because this allows for "verification and/or corroboration of one method by the other via triangulation, to enable or develop analysis, providing richer details, and to initiate new lines of thinking through attention to surprises or paradoxes, 'turning ideas around' and providing fresh insights" (Pansiri [27, p. 235]) 


\section{Conclusion}

Studies on tourism impacts are very important to any organization or government, be it at the local, state or central government level that concerns itself with tourism development. Understanding how communities are affected by tourism does not only help the planning and decision making processes in relation to tourism but also aid in the involvement of communities in tourism planning and decision making. Subsequently, this influences the support for tourism by local communities. The purpose of this paper has been to examine the perceived impact of tourism on urban and rural communities in Botswana. Like many other countries, Botswana has been vigorously developing and supporting tourism as a form of economic diversification. In selling these ideas, such countries need to be informed about the perceived impact that tourism has on their communities. Such knowledge helps in keeping community support for tourism.

In helping governments to evaluate and understand residents attitudes towards tourism development, researchers need to address the issue of perceived tourism impact assessment more holistically by addressing the attitudes of residents in relation to tourism strategies of particular destinations. Such an approach means that the target population for such research should also include decision makers and those responsible for implementing tourism strategies. Further to this, future research should consider triangulating methods with a view of getting comprehensive data on perceived tourism impacts.

\section{References}

[1] Commonwealth Sectretatiat. Botswana Targets Tourism for Economic Growth, Retrieved 01/04, 2007, from http://www.thecommonwealth.org /news/34580/34581/144143/botswana_targets_tourism_for_economic_gro wth.htm, 2005.

[2] Botswana Tourism Board. Training needs analysis of Botswana's tourism industry executive summary, Gaborone: Botswana tourism Board, 2009.

[3] Hospitality and Tourism Association of Botswana. Report on the tourism impact on SADC countries. Gaborone: Hospitality and Tourism Association of Botswana, 2006.

[4] Gutierrez, E., Lamoureux, K., Matus, S., \& Sebunya, K. Linking Communities, Tourism \& Conservation, Washington DC: Conservation International and The George Washington University, 2005.

[5] Butler, R. Tourism in the future: Cycles, waves or wheels? Futures, 41(6), 346-352, 2009.

[6] Haley, A. J., Snaith, T., \& Miller, G. The social impacts of tourism: A Case Study of Bath, UK. Annals of Tourism Research, 32(3), 647-668, 2005.

[7] Kibicho, W. Tourism and the Sex Trade in Kenya's Coastal Region. Journal of Sustainable Tourism, 13(3), 256-280, 2005. 
[8] Wilson, S., Fesenmaier, D. R., Fesenmaier, J., \& John C. van Es. Factors for Success in Rural Tourism Development. Journal of Travel Research, 40(2), 2001.

[9] Diedrich, A., \& Garc1'a-Buades, E. Local perceptions of tourism as indicators of destination decline. Tourism Management, 30(4), 512-521, 2009.

[10] Gursoy, D., Jurowski, C., \& Uysal, M. Resident attitudes: A Structural Modeling Approach Annals of Tourism Research, 29(1), 79-105, 2002.

[11] Gursoy, D., \& Rutherford, D. G. Host attitudes toward tourism: An Improved Structural Model Annals of Tourism Research, 31(3), 495-516, 2004.

[12] Dieke, P. U. C. Tourism in Africa's economic development: policy implications. Management Decision, 41(3), 287-295, 2003.

[13] Mbaiwa, J. E. The Socio-cultural Impacts of Tourism Development in the Okavango Delta, Botswana. Journal of Tourism and Cultural Change, 2(3), 163-184, 2004.

[14] Mbaiwa, J. E. Enclave tourism and its socio-economic impacts in the Okavango Delta, Botswana. Tourism Management, 26(2), 157-172, 2005a.

[15] Mbaiwa, J. E. The Problems and Prospects of Sustainable Tourism Development in the Okavango Delta, Botswana. Journal of Sustainable Tourism, 13(3), 203-227, 2005b.

[16] Government of Botswana. The Tourism Policy. Gaborone: Government Printer, 1990.

[17] Ndulamo, E. The economic impacts of tourism on the local people: The case of Maun in the Ngamiland Sub-District, Botswana. Msc Thesis. Department of Environmental Science, University of Botswana, Gaborone, 2000.

[18] Perdue, R. P. Resident Support for Tourism Development. Annals of Tourism Research, 17, 586-599, 1990.

[19] World Tourism Organisation. Workshop on Indicators of Sustainable Development for Tourism Destinations. Lombok, Indonesia, 2007.

[20] Pansiri, J. The effects of characteristics of partners on strategic alliance performance in the SME dominated travel sector. Tourism Management, 29(1), 101-115, 2008.

[21] Field, A. P. Discovering statistics using SPSS: (and sex, drugs and rock ' $n$ ' roll) (2nd. ed.). London: Sage, 2005.

[22] Nunnally, J. C. Psychometric theory. New York: McGraw-Hill, 1978.

[23] Papadakis, V. M., \& Barwise, P. How much do CEOs and top managers matter in strategic decision-making? British Journal of Management, 13(1), 83-95, 2002.

[24] Downward, P. M., \& Mearman, A. On tourism and hospitality management research: A critical realist proposal. Tourism and Hospitality Planning \& Development, 1(2), 107-122, 2004.

[25] Oppermann, M. Triangulation - a methodological discussion. International Journal of Tourism Research, 2(2), 141-145, 2000. 
[26] Pansiri, J. Pragmatism: A methodological approach to researching strategic alliances in tourism. Tourism and Hospitality: Planning \& Development, 2(3), 191-206, 2005.

[27] Pansiri, J. Doing tourism research using the pragmatist paradigm: An empirical example. Tourism and Hospitality: Planning \& Development, 3(3), 223-240, 2006. 